University of Nebraska - Lincoln

DigitalCommons@University of Nebraska - Lincoln

Faculty Papers and Publications in Animal

Science

Animal Science Department

1999

\title{
In Situ Neutral Detergent Insoluble Nitrogen as a Method for Measuring Forage Protein Degradability
}

\author{
R. Mass \\ University of Nebraska-Lincoln \\ G. P. Lardy \\ North Dakota State University \\ R. J. Grant \\ University of Nebraska-Lincoln \\ Terry Klopfenstein \\ University of Nebraska-Lincoln, tklopfenstein1@unl.edu
}

Follow this and additional works at: https://digitalcommons.unl.edu/animalscifacpub

Part of the Animal Sciences Commons

Mass, R.; Lardy, G. P.; Grant, R. J.; and Klopfenstein, Terry, "In Situ Neutral Detergent Insoluble Nitrogen as a Method for Measuring Forage Protein Degradability" (1999). Faculty Papers and Publications in Animal Science. 530.

https://digitalcommons.unl.edu/animalscifacpub/530

This Article is brought to you for free and open access by the Animal Science Department at DigitalCommons@University of Nebraska - Lincoln. It has been accepted for inclusion in Faculty Papers and Publications in Animal Science by an authorized administrator of DigitalCommons@University of Nebraska - Lincoln. 


\title{
In Situ Neutral Detergent Insoluble Nitrogen as a Method for Measuring Forage Protein Degradability ${ }^{1}$
}

\author{
R. A. Mass, G. P. Lardy², R. J. Grant, and T. J. Klopfenstein 3
}

Department of Animal Science, University of Nebraska, Lincoln 68583-0908

\begin{abstract}
A method of estimating the undegraded intake protein (UIP) concentration of forages was developed and validated with a series of in situ experiments. The hypothesis was that UIP calculated from in situ neutral detergent insoluble $\mathrm{N}$ (NDIN) is equal to total in situ $\mathrm{N}$ minus the microbial $\mathrm{N}$ that is estimated from purines $(\mathrm{MN})$. The in situ disappearance rates of total in situ N (TN), $\mathrm{MN}$, and NDIN were measured for six hay samples and two range masticate samples. Hypothetical rates of passage ( 2 or $5 \% / \mathrm{h}$ ) were used to calculate UIP ( $\%$ of DM) for each $N$ pool. Estimates of UIP from TN were higher $(P=.0001)$ than those from either $M N$ or NDIN, and MN estimates of UIP were similar ( $P=$ .48) to NDIN estimates. A low-N fiber source (solka floc) was incubated in situ for $8 \mathrm{~h}$. Analysis of the
\end{abstract}

residue detected purines before, but not after, neutral detergent extraction. Several in situ incubation (i.e., Dacron bag size and number of Dacron bags in a mesh bag) and neutral detergent extraction conditions were tested. None of the factors tested affected in situ NDIN disappearance $(P>.05)$. The hypothesis that NDIN is completely digestible in the rumen was tested. Estimates of the extent of NDIN digestion were made using 96-h in situ incubations, and UIP was recalculated for the test samples. Mean in situ UIP concentration decreased upon recalculation $(P=.05)$. In situ NDIN provides estimates of forage UIP that are equal to estimates from MN. Forage UIP estimates are less when extent of $\mathrm{N}$ degradation is estimated and included in the calculation.

Key Words: Forage, Protein, Degradation

○1999 American Society of Animal Science. All rights reserved.

J. Anim. Sci. 1999. 77:1565-1571

\section{Introduction}

The National Research Council's Nutrient Requirements of Beef Cattle (NRC, 1996) has adopted a metabolizable protein (MP) system. This system is based on protein that originates from 1 ) the rumen microflora, 2) endogenous protein loss, and 3) undegraded intake protein of feedstuffs (UIP). Few estimates of forage UIP are available in the literature, and a method for estimating forage UIP is needed. Although many UIP methods exist, the most popular method is the in situ bag method (Broderick, 1994). Microbial contamination of in situ residue is a problem (Michalet-Doreau and Ould-Bah, 1992). Although microbial correction methods exist (Zinn and Owens, 1986), they are labor-intensive and imprecise. Sniffen et al. (1992) hypothesized that

\footnotetext{
${ }^{1}$ Assigned J ournal Series No. 12217, Agric. Res. Division, Univ. of Nebraska.

${ }^{2}$ Current address: Dept. of Anim. Sci., North Dakota State Univ., Fargo.

3To whom correspondence should be addressed.

Received May 18, 1998.

Accepted November 19, 1998.
}

neutral detergent insoluble N (NDIN) is the primary UIP fraction of feedstuffs. Our objectives were 1) to test the use of in situ NDIN as an estimate of forage UIP relative to both total in situ $\mathrm{N}$ and microbialcorrected $\mathrm{N}$ and 2 ) to develop an improved in situ method by testing factors related to in situ incubation and neutral detergent extraction.

\section{Materials and Methods}

\section{Experiment 1}

A standard in situ method was used (Wilkerson et al., 1995). Dacron bags were purchased $(10 \times 20 \mathrm{~cm}$, 53- $\mu \mathrm{m}$ pore size; Ankom, F airport, NY). Samples were ground to pass through a $2-\mathrm{mm}$ screen, and $5 \mathrm{~g}$ of sample was added to each bag. Samples incubated were two alfalfa (Medicago sativa L.) hays, two subirrigated meadow hays (mixed cool-season grass species), one smooth bromegrass (Bromus inermis Leyss.) hay, one prairie hay (mixed warm- season grass species), and two native range masticate samples (mixed warm-season grass species) that were collected using esophageally fistulated cows. Solka floc was incubated to provide a low-N fiber source for 
Table 1. Classification of forages based on CP (\%) and IVDMD (\%) (Exp. 1)

\begin{tabular}{lrcc}
\hline \hline Sample & CP & IVDMD & Classification \\
\hline Smooth bromegrass hay & 14.4 & 66.2 & High \\
Prairie hay & 6.8 & 53.4 & Low \\
Alfalfa hay \#1 & 20.3 & 67.2 & High \\
Alfalfa hay \#2 & 30.0 & 73.9 & High \\
Meadow hay \#1 & 7.7 & 49.4 & Low \\
Meadow hay \#2 & 16.2 & 67.3 & High \\
Range masticate sample \#1 & 5.6 & 52.1 & Low \\
Range masticate sample \#2 & 12.0 & 68.0 & High \\
\hline
\end{tabular}

${ }^{a}$ Classification of forages was made based on the two quality traits. Samples higher than 10\% CP and 60\% IVDMD were classified as high-quality ( $\mathrm{High}$ ). Samples that did not meet these minimum criteria were classified as low-quality (Low).

testing the ability of neutral detergent solution to remove attached microbes. Fistulated cattle were developed according to surgical procedures approved by the University of Nebraska Animal Care and Use Committee.

Samples were analyzed for CP and IVDMD (Table $1)$. Crude protein was analyzed with the combustion method (AOAC, 1996) using a $\mathrm{N}$ analyzer (PerkinEImer, Norwalk, CT), and IVDMD was determined using the method of Tilley and Terry (1963), modified by the addition of $1 \mathrm{~g}$ of urea/L of inoculum (Weiss, 1994). Quality classifications were made based on the following criteria: samples with greater than $10 \% \mathrm{CP}$ and $60 \%$ IVDMD were classified as high-quality, whereas samples that did not meet those minimum criteria were classified as low-quality.

Samples were incubated in a ruminally fistulated steer ( $725 \mathrm{~kg} \mathrm{BW})$ that was fed smooth bromegrass hay ( $8 \%$ CP) once daily at $1.8 \%$ of BW. All incubations began at the time of feeding. Bags were removed at the same time and washed together. Highquality samples were incubated for 4,10 , and $16 \mathrm{~h}$, and low-quality samples were incubated for 8,16 , and $24 \mathrm{~h}$. Each set of incubation times was replicated on three consecutive days. One bag per sample was included on each day.

Bags were rinsed and dried at $60^{\circ} \mathrm{C}$ for $16 \mathrm{~h}$. The residue in each bag was subsampled as-is and analyzed for three pools of $\mathrm{N}$. The first pool, total residual $\mathrm{N}$ ( TNN), was measured using the combustion method (AOAC, 1996). The second pool, microbialcorrected N ( $\mathbf{M N})$, was measured using the purine method of Zinn and Owens (1986) and was calculated as the difference of TN minus attached microbial $\mathrm{N}$ estimated from purines. The third pool, neutral detergent insoluble N (NDIN), was measured by conducting the neutral detergent extraction procedure on the residue (Van Soest et al., 1991) and subsequently analyzing that residue for $\mathrm{N}$ by the combustion method (AOAC, 1996). The neutral detergent solution did not contain sodium sulfite, which is often used to reduce $\mathrm{N}$ content of NDF, because the cleavage of disulfide bridges by sodium sulfite is not a biological possibility (Licitra et al., 1996).

A purine $\mathrm{N}$ :total microbial $\mathrm{N}$ ratio (.137) for the particle-attached microbes of the in situ residue was determined in a separate subexperiment. The ratio was used to calculate the amount of microbial $\mathrm{N}$ present in the in situ residue. This ratio was estimated by incubating smooth bromegrass NDF in situ for $16 \mathrm{~h}$. Five bags ( $5 \mathrm{~g} / \mathrm{bag}$ ) were incubated on each of two consecutive days. Bags were rinsed and dried at $60^{\circ} \mathrm{C}$ for $16 \mathrm{~h}$. A subsample of the residue in each bag was then analyzed for TN and purines both before and after neutral detergent extraction. Neutral detergent removed all purines, and $\mathrm{N}$ associated with the microbial population was calculated as total $\mathrm{N}$ prior to neutral detergent extraction minus total $\mathrm{N}$ after neutral detergent extraction. Because the in situ NDF residue did not contain neutral detergent soluble $\mathrm{N}$ of feed origin, the only $\mathrm{N}$ removed by neutral detergent after incubation would be microbial $\mathrm{N}$. The standard curve used for purines was based on serial dilutions of a solution of $.5 \mathrm{~N}$ hydrochloric acid that contained adenine and guanine mixed in a $1: 1$ ratio (wt/wt; Sigma Chemical Co., St. Louis, MO).

Rates of ruminal disappearance for each in situ $\mathrm{N}$ pool were calculated. A first-order disappearance model was assumed (Mertens, 1987). Pool N for each bag (mg pool N/g of sample incubated) was transformed to fit the model by calculating the natural logarithm of pool $\mathrm{N}$. The three transformed data points for each incubation were used to determine the slope $\left(\mathbf{k}_{\mathbf{d}}\right)$. The original pool size for each sample was estimated by calculating the $\mathrm{Y}$-intercept (i.e., In) and transforming that point to its original units $(\mathrm{mg} / \mathrm{g})$. There are at least four reasons why we chose to extrapolate to $0 \mathrm{~h}$ for the original pool rather than using direct determination. First, both methods estimate the same original pool, conceptually, which is the neutral detergent insoluble $\mathrm{N}$ pool; according to Sniffen et al. (1992) this is the $B_{3}$ fraction. Second, initial pool size and $k_{d}$ interact because there is variation around each of the time points. If the pool size predicted by regression to $0-\mathrm{h}$ is used, it tends to correct for this variation. For example, a slightly higher estimate for $k_{d}$ also estimates a larger pool size, and the two used together in the formula at least partially compensate for each value being high to more accurately predict UIP. Third, regressing to 0-h to obtain pool size decreases the number of analyses by one, saving time and money. Fourth, samples at 4 and $12 \mathrm{~h}$, for example, have been influenced by ruminal conditions, such as bag washing, small particle washout, microbial attachment, fermentation, and so on. Therefore, it seems that the $0-h$ value by regression more nearly represents the correct pool than that derived by a simple extraction of the original sample.

An original $\mathrm{N}$ pool and $\mathrm{k}_{d}$ were calculated for each of the three incubations. Theoretical rates of passage 
( $\mathbf{k}_{\mathbf{p}}$ ) were used to calculate UIP ( $\%$ of DM ). A rate of $2 \% / \mathrm{h}$ was used for the low-quality samples and a rate of $5 \% / h$ was used for the high-quality samples. The following equation was used (Broderick, 1994): UIP $(\%$ of $D M)=\left(k_{p} /\left(k_{p}+k_{d}\right)\right) \times$ original $N$ pool $\times 6.25$.

The statistical analysis of the UIP estimates was based on a completely randomized design (Snedecor and Cochran, 1989) using the GLM procedure of SAS (1988). Means were separated using Fisher's least significant difference test. Significance was declared for all hypothesis tests at the level $\mathrm{P}=.05$.

Experiments 2, 3, and 4

All three experiments were conducted under the same animal incubation conditions as Exp. 1. The purpose of these experiments was to investigate the effect of adapting the standard in situ method used in Exp. 1 to make it more efficient and automated. Each experiment consisted of one 16-h incubation. The same lot of neutral detergent solution was used for all analyses. The smooth bromegrass hay from Exp. 1 was incubated in every bag. Four bags were incubated for each level of each factor. Estimates of UIP (mg NDIN/ g sample incubated) were calculated, and a separate statistical analysis was conducted for each experiment using the GLM procedure of SAS (1988). Significance was declared for all hypothesis tests at the level $\mathrm{P}=$ .05 .

Experiment 2 was designed to test modifications made to allow bulk refluxing of in situ residue in neutral detergent solution. The experiment was conducted as a completely randomized design with a $2 \times 4$ factorial treatment structure. Factors tested were (standard conditions listed first): in situ bag size (10 $\times 20 \mathrm{~cm}$ vs $5 \times 10 \mathrm{~cm})$, degree of post-in situ hand rinsing (45 vs $15 \mathrm{~min}$ ), bag closure method (rubber band around a \#8 rubber stopper vs heat sealing), and NDF method (individual refluxing of subsampled residue vs bulk refluxing of the bag containing its residue). The amount of sample incubated in the small bags was reduced to maintain the sample:bag surface area ratio of Exp. 1 ( 5 vs $1.25 \mathrm{~g}$ ). The same number of rubber stoppers was placed in the mesh bags containing heat-sealed in situ bags to ensure similar weights for each mesh bag. A bulk refluxing apparatus was used for the NDF analyses (Ankom). All stoppered bags were heat-sealed prior to bulk refluxing.

Experiment 3 was conducted as a completely randomized design with $2 \times 2$ factorial treatment structure. All in situ bags were $5 \times 10 \mathrm{~cm}$ and contained $1.25 \mathrm{~g}$ of sample. Bags were hand-rinsed for 15 min immediately after the incubation. The bags were heat-sealed and refluxed in neutral detergent solution in the bulk apparatus. The first factor tested the effect of in situ bag density within a mesh bag. In situ bags were incubated in the steer at two densities (20 bags/mesh bag vs 50 bags/mesh bag). Two mesh bags were incubated for each density. The second factor concerned the refluxing conditions. Use of the bulk reflux apparatus requires placement of the in situ bags in a cylindrical rack. The rack consists of eight removable dishes. Each dish is capable of holding three in situ bags, for a total of 24 bags possible in each reflux. Dishes are stacked vertically and a metal rod holds them together. Our hypothesis was that there was no effect of dish position on NDIN content. The top and bottom two racks were used as the two levels of the second experimental factor. Six bags from each mesh bag density (three per replication) were chosen randomly and allotted randomly to either the top or bottom level of the two refluxes that were conducted. The top or bottom dish held one or two bags from each mesh bag density during the first reflux and the alternate number in the second reflux.

Experiment 4 was conducted as a completely randomized design with a $2 \times 2$ factorial treatment structure. Small, heat-sealed in situ bags $(5 \times 10 \mathrm{~cm})$ were incubated at a density of 50 bags/mesh bag. Bags contained $1.25 \mathrm{~g}$ of sample and were rinsed after incubation for $15 \mathrm{~min}$. Bags were assigned randomly to dishes in the bulk reflux rack. The first factor tested the sensitivity of in situ NDIN content to time of reflux. Bags were refluxed in neutral detergent solution for either 40 or $70 \mathrm{~min}$. The second factor tested the sensitivity of in situ NDIN content to extent of post-extraction bag rinsing. Bags were rinsed in boiling distilled water at the rate of either .5 or $1 \mathrm{~L}$ water/bag.

\section{Experiment 5}

Three sets of forage samples were incubated together in the rumen to determine the relationship between rates of in situ NDIN digestion $\left(\mathrm{k}_{\mathrm{d}}\right)$ calculated with or without correction for extent of ruminal NDIN digestion. Masticate samples were collected from animals grazing the following forages: corn (Zea mays L.) stover ( $n=24)$, cool-season grasses ( $n=$ $36)$, and winter native range $(n=24)$. The 252 samples were randomly assigned to three mesh bags. Three separate incubations were conducted on consecutive days in the rumen of the same animal as Exp. 1.

All of the incubation modifications made in Exp. 4 were used. Small bags $(5 \times 10 \mathrm{~cm})$ were heat-sealed and incubated at a rate of 50 to 51 bags/mesh bag. Bags were randomly selected for refluxing in neutral detergent solution in groups of 24 at a time. Each sample was incubated for 2, 12, or $96 \mathrm{~h}$. Incubations were replicated three times on $3 \mathrm{~d}$. The $k_{d}$ for each incubation was calculated in one of two ways. In the first (NDIN method), $k_{d}$ was calculated in the same manner as Exp. 1. This calculation assumes that NDIN is $100 \%$ degradable in the rumen. In the second (96NDIN method), $k_{d}$ was calculated by subtracting the 96-h value from both the 2 - and 12 -h values 


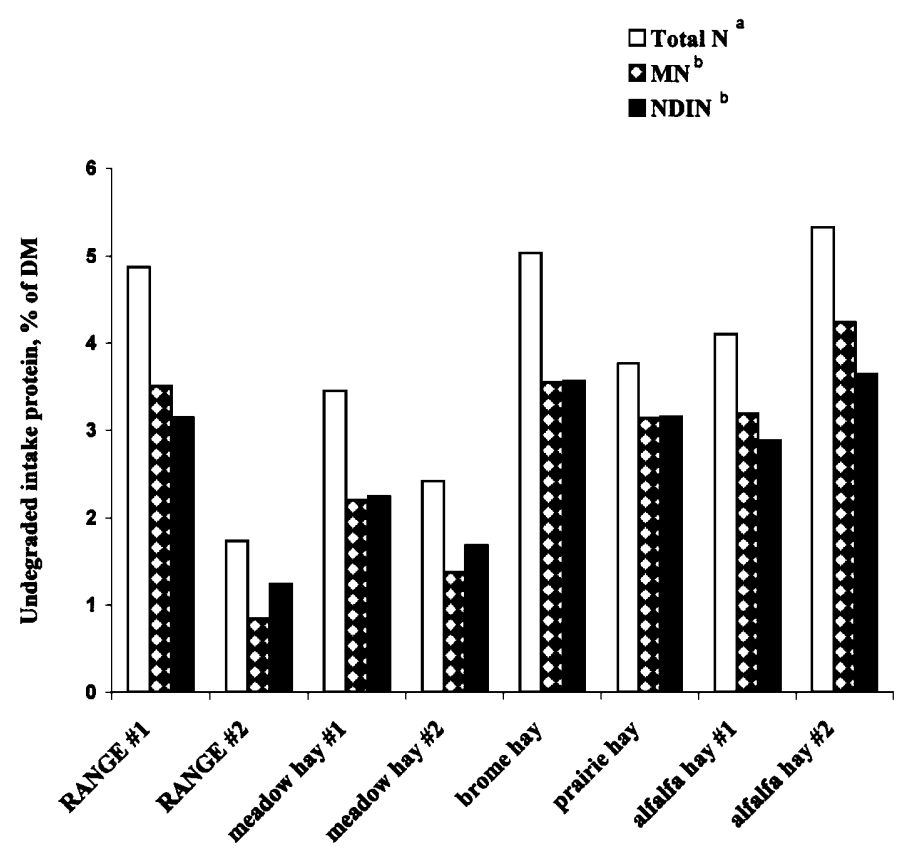

Figure 1. Undegraded intake protein (UIP, \% of DM) estimates of two range masticate samples (RANGE) and six hay samples using three pools of in situ N: total $\mathrm{N}$ (TN), microbial-corrected $\mathrm{N}(\mathrm{MN})$, and neutral detergent insoluble N (NDIN; Exp. 1). Pools lacking a different superscript letter differ $(\mathrm{P}<.05)$.

(Mertens, 1987). These new values were used to calculate a new slope and original pool. The second calculation assumes that the NDIN pool has reached its extent of ruminal degradation by $96 \mathrm{~h}$. The relationship between the two rates was analyzed using the regression procedure of SAS (1988); NDIN was the independent variable and 96NDIN was the dependent variable. Significance was declared for all hypothesis tests at the level $\mathrm{P}=.05$.

\section{Results and Discussion}

\section{Experiment 1}

Estimates of UIP concentration ( $\%$ of DM) calculated from in situ disappearance data for each of the three $\mathrm{N}$ pools are shown in Figure 1 . Estimates made by $T N$ were higher $(P=.05)$ than those calculated using MN or NDIN. Estimates calculated using MN were not different $(P=.48)$ from those calculated using NDIN. There was a forage sample $\times$ method interaction $(\mathrm{P}=.02)$ for the UIP estimates. We interpret the interaction to be the result of variable amounts of microbial $\mathrm{N}$ that is not accounted for by the TN method. The presence of attached microbes on in situ residue would cause variable UIP estimates when the TN method is used. However, both the MN and NDI N methods isolate the $\mathrm{N}$ that is separate from microbial $\mathrm{N}$. The fact that TN UIP estimates are higher than the MN and NDIN estimates indicates that some type of correction for microbial attachment is indeed necessary, whether by measuring the concentration of attached microbial $\mathrm{N}$ (as with purines) or by removing them (as with NDIN). Attached microorganisms make up 50 to $65 \%$ of rumen particle $\mathrm{N}$ and 17 to $27 \%$ of particle DM (Craig et al., 1987). Results vary according to the kind of microbial marker used (Michalet-Doreau and Ould-Bah, 1992). The fact that MN and NDIN gave similar UIP results indicates that both methods measure the same in situ $\mathrm{N}$ pool.

The TN method was removed from the statistical analysis in order to evaluate the MN and NDIN methods. Overall mean values for the two methods were not different $(2.75$ and $2.70 \%$ UIP, for $\mathrm{MN}$ and NDIN, respectively). The forage sample $\times$ method interaction was $P=.17$. This suggests that the two methods were consistent in how they evaluated samples, but the P-value was low enough to warrant further evaluation. The MN values were regressed on the NDIN values (Figure 2 ). The methods would predict similar values if the intercept was zero, the slope was 1 , and the $r^{2}$ was high. The $r^{2}$ was high (.96) but the slope was .74 and the intercept was .65. The NDIN procedure predicts MN values quite well, but application of the regression equation may be necessary to predict absolute values. Conversely, the NDIN values may be accurate and the $M N$ values may be biased because of inadequacy of purine analysis or the purine $\mathrm{N}: \mathrm{N}$ ratio in predicting microbial $\mathrm{N}$ attachment. Further analyses over a range of samples will be needed to document the relationship of $M N$ and NDIN methods. An in vivo (absolute) standard is needed and is very difficult to determine as well.

The conclusion that NDIN is simpler than MN is logical when the nature of the two methods is considered. The NDIN procedure consists of refluxing the residue in neutral detergent solution, rinsing, drying, and analyzing for $\mathrm{N}$. Conversely, $\mathrm{MN}$ is an extraction process consisting of several steps, each adding time to the method. The use of microbial markers such as purines requires the existence of a reference bacterial sample in order to calculate the ratio of purine $\mathrm{N}$ :total microbial $\mathrm{N}$ from the purine concentration in the residue (Michalet-Doreau and Ould-Bah, 1992). This reference sample must represent the proper physical phase of the microbial population. Several of these ratios have been calculated (Nocek and Grant, 1987). Our ratio was calculated to estimate the purine $\mathrm{N}$ :total microbial $\mathrm{N}$ ratio of the microbes attached to the in situ residue.

Our hypothesis that in situ NDIN provides a simple estimate of UIP assumes that refluxing in situ residue in neutral detergent solution removes all attached microbes. Our hypothesis was tested by the in situ incubation of solka floc. This delignified, highly digestible fiber is a byproduct of the wood pulping industry (Van Soest, 1994). The original solka floc 


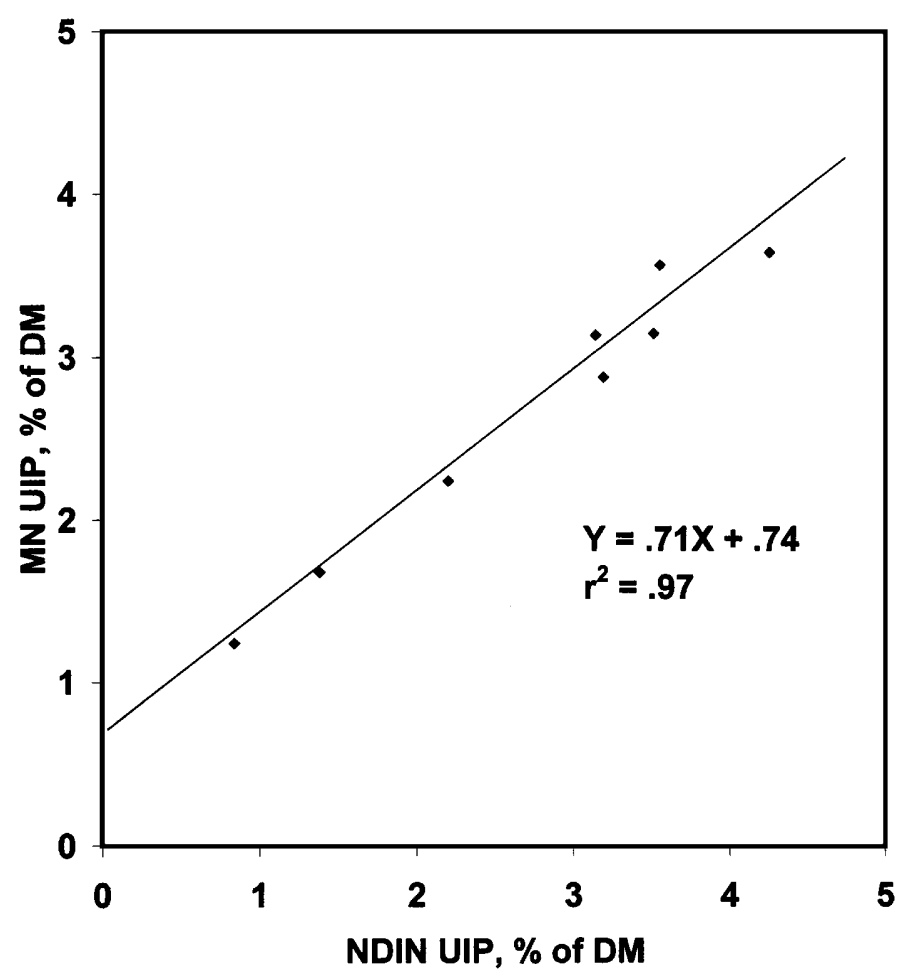

Figure 2. Relationship of undegraded protein (UIP) using microbial correction (MN) to UIP using neutral detergent extraction (NDIN).

contained $.10 \% \mathrm{~N}$ and $.12 \%$ purines. The in situ residue contained a mean value of $.47 \% \mathrm{~N}$ and $.48 \%$ purines ( $n=6$ bags; DM basis) after water rinsing and $.10 \% \mathrm{~N}$ with $.11 \%$ purines after neutral detergent extraction. The in situ residue had an NDF content of $97 \%$. These results confirm that in situ residue has microbes attached to it after water rinsing and that refluxing the residue in neutral detergent solution removes them.

\section{Experiment 2}

No differences were observed among the different factors tested in Exp. 2 and no interactions between factors were detected (Table 2 ). The effect of bag size on in situ DM disappearance of forages has been investigated (Playne et al., 1978). No effect of increasing bag size by a factor of four was observed, as long as the same sample size:bag surface area ratio was maintained. The results of our experiment agree with that conclusion. Digestibility of concentrates and forages is increased when the sample size:bag surface area ratio is decreased (Mehrez and Ørskov, 1977).

Rinsing of bags after in situ incubation is necessary for the removal of ruminal microbes from the bag and its residue (Mehrez and Ørskov, 1977). Many techniques for bag rinsing have been studied (Varvikko and Lindberg, 1985; Nocek and Grant, 1987; Wilkerson et al., 1995). Under ideal conditions, all microbes are removed by rinsing, so that DM and $\mathrm{N}$ digestibili-
Table 2. Effect of modifications (in situ bag size, rinsing, closure, and neutral detergent extraction method) on 16-h in situ neutral detergent insoluble N (NDIN) content (Exp. 2)

\begin{tabular}{lcc}
\hline \hline $\begin{array}{l}\text { Factor tested } \\
\text { and condition }\end{array}$ & $\begin{array}{l}\text { mg NDIN/ } \\
\text { g sample }\end{array}$ & P-value \\
\hline $\begin{array}{l}\text { In situ bag size } \\
10 \times 20 \mathrm{~cm}\end{array}$ & .15 \\
$5 \times 10 \mathrm{~cm}$ & 4.52 & \\
Length of rinse & 4.33 & .42 \\
45 min & 4.31 & \\
15 min & 4.44 & .10 \\
Bag closure & & \\
Rubber-banded & 4.23 & \\
Heat-sealed & 4.53 & .08 \\
Extraction method & & \\
Individual & 4.54 & \\
Bulk reflux & 4.22 & \\
\hline
\end{tabular}

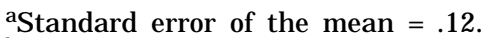

${ }^{\mathrm{b}} \mathrm{F}$ or each given factor.

ties are not underestimated, while DM washout is minimized, so that these digestibilities are not overestimated. However, microbial attachment to in situ residue was detected in this case. It was hypothesized that less rinsing would be necessary if NDIN was used as the pool to calculate UIP. The results of Exp. 1 indicate that neutral detergent solution reflux would remove attached microbes. Therefore, prolonged rinsing immediately after incubation may be unnecessary. No differences were observed in 16-h NDIN content between bags rinsed for 45 vs $15 \mathrm{~min}$ (Table 2 ). Reduction in the time spent washing makes the method more efficient and might reduce washout of small particles.

No effect of method of bag closure and neutral detergent extraction method was found (Table 2). The procedure of Wilkerson et al. (1995) called for wrapping each bag around a \#8 rubber stopper and attaching it with two \#18 rubber bands. However, it is necessary to heat-seal the bags when the neutral detergent extraction is conducted directly on the bag

Table 3. Effect of modifications (mesh bag density and neutral detergent reflux) on 16-h in situ neutral

detergent insoluble N (NDIN) content (Exp. 3)

\begin{tabular}{lcc}
\hline \hline $\begin{array}{l}\text { Factor tested } \\
\text { and condition }\end{array}$ & $\begin{array}{c}\text { mg NDIN/ } \\
\text { g sample }\end{array}$ & P-value $^{\mathrm{a}}$ \\
\hline Mesh bag density & & \\
20 bags/bag & 4.51 & .09 \\
50 bags/bag & 4.25 & \\
Reflux position & & \\
Top of rack & 4.44 & .37 \\
Bottom of rack & 4.32 & \\
\hline
\end{tabular}

aStandard error of the mean $=.13$.

${ }^{b} \mathrm{~F}$ or each given factor. 
Table 4. Effect of modifications (time of neutral detergent reflux and amount of post-extraction bag rinse) on 16-h in situ neutral detergent insoluble $\mathrm{N}$ (NDIN) content (Exp. 4)

\begin{tabular}{lcc}
\hline \hline $\begin{array}{l}\text { Factor tested } \\
\text { and condition }\end{array}$ & $\begin{array}{c}\text { mg NDIN/ } \\
\text { g sample }\end{array}$ & P-value $^{\mathrm{b}}$ \\
\hline Time of reflux & & \\
$40 \mathrm{~min}$ & 4.50 & .91 \\
$70 \mathrm{~min}$ & 4.49 & \\
Amount of bag rinse (after extraction) & \\
$.5 \mathrm{~L} /$ bag & 4.44 & .44 \\
$1.0 \mathrm{~L} / \mathrm{bag}$ & 4.49 & \\
\hline
\end{tabular}

aStandard error of the mean $=.06$.

${ }^{b} \mathrm{~F}$ or each given factor.

and its residue. The results of Exp. 2 indicate that the NDIN procedure can be conducted using smaller, heatsealed bags that are rinsed for 15 min after incubation and refluxed in bulk.

\section{Experiments 3 and 4}

No effect of mesh bag density was observed and no bag density $\times$ reflux rack position interaction was detected ( $P<.05$; Table 3 ). Ther efore, up to 50 in situ bags can be placed in one mesh bag and up to 300 in situ bags $(5 \times 10 \mathrm{~cm})$ can be incubated in the rumen of a large bovine. These findings are in contrast to standard in situ methods that allow for no more than 20 in situ bags in one mesh bag and up to six mesh bags in one ruminal incubation. We are unaware of reports on maximum numbers of bags that can be placed in an animal without affecting rates of degradation. A $400-\mathrm{kg}$ animal has about $40 \mathrm{~L}$ of ruminal contents. The mesh bags are $36 \times 42 \mathrm{~cm}$ and have a 4- to 5-cm average width when filled with 50, 5 $\times 10 \mathrm{~cm}$ bags (heat-sealed). This is a volume of approximately $7,000 \mathrm{~cm}^{2}$ per mesh bag. It is not unreasonable to believe that six bags would be accommodated in a 40-L rumen. The sample DM would be $450 \mathrm{~g}$, which would be less than $5 \%$ of DM intake. Similarly, no effect was found for the position of bags within the bulk refluxing apparatus (Table 3 ). Bags may be allotted randomly to any dish in the bulk reflux rack without affecting NDIN content. No effect of either reflux time or amount of post-extraction rinsing was observed, and no reflux time $\times$ rinsing interaction was detected in Exp. 4 (Table 4). These results imply that reflux time and extent of rinsing within the ranges used in the present experiment are not critical to the method.

\section{Experiment 5}

The estimates of UIP made in Exp. 1 assume that NDIN is $100 \%$ digestible in the rumen. However, this assumption is inconsistent with cell wall digestion models, which assume that ruminally undegraded fiber is present (Mertens, 1987). The importance of an accurate estimate of the $k_{d}$ for a protein fraction has been shown (Ørskov and McDonald, 1979). The purpose of this experiment was to describe the effect of correcting the NDIN $k_{d}$ for an undegraded $\mathrm{N}$ fraction. The pool remaining after $96 \mathrm{~h}$ was assumed to be undegradable in the rumen. Values for the 96-h undegraded $\mathrm{N}$ fraction for the three sample sets ranged only from .28 to .33\% of DM. Values for the eight samples from Exp. 1 varied from .26 to $.34 \%$ of DM. This suggests a very small difference in 96-h undegraded $\mathrm{N}$ values across a wide range of forages (5.6 to $30 \% \mathrm{CP}$ ).

The regression equations that describe the relationship between values corrected for the 96-h undegradable fraction vs uncorrected values for each sample set are shown in Table 5. Each equation explained a high proportion of the variation in NDIN $k_{d}$ (i.e., $r^{2}$ values $\geq .80$ ). These results imply a close relationship between the two rates. However, it would be necessary to have a separate equation for each sample set because each had a different slope and Y-intercept. The same slopes were obtained when a random subset (10\%) of samples in each set was analyzed in the same manner (data not shown). These equations can be used to adjust $k_{d}$ when extent of ruminal degradation (96-h) is not measured. The ability to obtain such an equation by conducting 96-h incubations on $20 \%$ of the samples in a set reduces the cost incurred for the analysis.

The UIP estimates made in Exp. 1 were recalculated after correcting rates of NDIN digestion for undegradability (Table 6). Mean UIP content was reduced by $24 \%$ ( $P=.05$ ). The effect of correcting UIP estimates for extent of ruminal degradability is clear.

Table 5. Regression equations for correcting the rate of in situ neutral detergent insoluble N (NDIN) digestion for an undegradable fraction (Exp. 5)

\begin{tabular}{lcll}
\hline \hline Sample set & $\mathrm{n}$ & Equation $^{\mathrm{a}}$ & $\mathrm{r}^{2}$ \\
\hline Native winter range & 24 & $.468+1.174 \mathrm{X}+.023 \mathrm{X}^{2}$ & .95 \\
Corn stalks & 24 & $.584+.956 \mathrm{X}+.035 \mathrm{X}^{2}$ & .94 \\
Cool-season grasses & 36 & $.176+1.221 \mathrm{X}+.051 \mathrm{X}^{2}$ & .80 \\
Combination of all sets & 84 & $.400+1.227 \mathrm{X}+.028 \mathrm{X}^{2}$ & .85 \\
\hline
\end{tabular}

${ }^{a} X=$ uncorrected rate of digestion calculated from 2 - and 12 -h in situ NDIN contents. 
Table 6. Effect of correcting the rate of in situ neutral detergent insoluble $\mathrm{N}$ (NDIN) digestion on undegraded intake protein (UIP, \% of DM) content

\begin{tabular}{lcc}
\hline \hline Sample & NDIN $^{\mathrm{a}}$ & 96NDIN $^{\mathrm{b}}$ \\
\hline Smooth bromegrass hay & 3.82 & 2.53 \\
Prairie hay & 3.38 & 2.13 \\
Alfalfa hay \#1 & 3.19 & 2.38 \\
Alfalfa hay \#2 & 3.96 & 3.37 \\
Meadow hay \#1 & 1.82 & 1.48 \\
Meadow hay \#2 & 2.49 & 2.27 \\
Range masticate sample \#1 & 3.44 & 2.40 \\
Range masticate sample \#2 & 1.35 & 1.13 \\
Method mean $^{c}$ & $2.93^{\mathrm{d}}$ & $2.21^{\mathrm{e}}$ \\
\hline
\end{tabular}

${ }^{a}$ NDIN equals the method shown in Figure 1.

b96NDIN equals NDIN corrected for a 96-h indigestible fraction. 'Standard error of the mean $=.07$.

d,eWithin a row, means lacking a common superscript letter differ $(P<.05)$.

\section{Implications}

The modified in situ neutral detergent insoluble nitrogen method can serve as an accurate laboratory method of estimating forage undegradable intake protein. Results obtained are similar to accepted microbial correction methods (i.e., purines), making it a valid alternative to such a method. Extent of forage neutral detergent insoluble nitrogen digestion can be estimated by analyzing a portion of the sample set for 96-h degradability and developing a prediction equation for that sample set. This equation then can be used to correct measured rates of ruminal digestion for that sample set. Information obtained with this method will contribute to more accurate use of metabolizable protein systems.

\section{Literature Cited}

AOAC. 1996. Official Methods of Analysis (16th Ed.). Association of Official Analytical Chemists, Arlington, VA.

Broderick, G. A. 1994. Quantifying forage protein quality. In: G. C. Fahey, J r. (E d.) Forage Quality, Evaluation, and Utilization. pp 200-228. American Society of Agronomy, Inc., Crop Science Society of America, Inc., and Soil Science Society of America, Inc., Madison, WI.

Craig, W. M., G. A. Broderick, and D. B. Ricker. 1987. Quantitation of micro-organisms associated with the particulate phase of ruminal ingesta. J. Nutr. 117:56-62.
Licitra, G., T. M. Hernandez, and P. J . Van Soest. 1996. Standardization of procedures for $\mathrm{N}$ fractionation of ruminant feeds. Anim. Feed Sci. Technol. 57:347-358.

Mehrez, A. Z., and E. R. Ørskov. 1977. A study of the artificial fibre bag technique for determining the digestibility of feeds in the rumen. J . Agric. Sci. 88:645-650.

Mertens, D. R. 1987. Predicting intake and digestibility using mathematical models of ruminal function. J. Anim. Sci. 64: 1548-1558.

Michalet-Doreau, B., and M. Y. Ould-Bah. 1992. In vitro and in sacco methods for the estimation of dietary $\mathrm{N}$ degradability in the rumen: A review. Anim. Feed Sci. Technol. 40:57-86.

Nocek, J. E., and A. L. Grant. 1987. Characterization of in situ nitrogen and fiber digestion and bacterial nitrogen contamination of hay crop forages preserved at different dry matter percentages. J. Anim. Sci. 64:552-564.

NRC. 1996. Nutrient Requirements of Beef Cattle (7th Ed.). National Academy Press, Washington, DC.

Ørskov, E. R., and I. McDonald. 1979. The estimation of protein degradability in the rumen from incubation measurements weighted according to rate of passage. J . Agric. Sci. 92:499-503.

Playne, M. J., W. Khumnualthong, and M. G. Ecevarria. 1978. Factors affecting the digestion of oesphageal fistula samples and hay samples in nylon bags in the rumen of cattle. J . Agric. Sci. (Camb.) 90:193-204.

SAS. 1988. SAS/STAT ${ }^{\circledR}$ User's Guide (Release 6.03). SAS Inst. Inc., Cary, NC.

Snedecor, G. W., and W. G. Cochran. 1989. Statistical Methods (8th Ed.). Iowa State Univ. Press, Ames.

Sniffen, C. J ., J . D. O'Connor, P. J . Van Soest, D. G. Fox, and J .B. Russell. 1992. A net carbohydrate and protein system for evaluating cattle diets: II. Carbohydrate and protein availability. J . Anim. Sci. 70:3562-3577.

Tilley, J .M.A., and R .A. Terry. 1963. A two-stage technique for the in vitro digestion of forages. J. Br. Grassl. Soc. 18:104-111.

Van Soest, P. J. 1994. Nutritional Ecology of the Ruminant (2nd Ed.). Cornell University Press, Ithaca, NY.

Van Soest, P. J ., J . B. Robertson, and B. A. Lewis. 1991. Methods for dietary fiber, neutral detergent fiber, and non-starch polysaccharides in relation to animal nutrition. J. Dairy Sci. 74: 3583-3597.

Varvikko, T., and J . E. Lindberg. 1985. Estimation of microbial $\mathrm{N}$ in nylon-bag residues by feed ${ }^{15} \mathrm{~N}$ dilution. Br. J. Nutr. 54: 473-481.

Weiss, W. P. 1994. Estimation of digestibility of forages by laboratory methods. In: G. C. Fahey, J r. (E d.) Forage Quality, Evaluation, and Utilization. pp 644-681. American Society of Agronomy, Inc., Crop Science Society of America, Inc., and Soil Science Society of America, Inc., Madison, WI.

Wilkerson, V. A., T. J. Klopfenstein, and W. W. Stroup. 1995. A collaborative study of in situ forage protein degradation. J. Anim. Sci. 73:583-588.

Zinn, R. A., and F. N. Owens. 1986. A rapid procedure for purine measurements and its use for estimating net ruminal protein synthesis. Can. J. Anim. Sci. 66:157-165. 